\title{
Proximity, maps and conflict: new measures, new maps and new findings
}

\author{
Steve Pickering* \\ This is the final version submitted to CMPS. The definitive \\ version should be considered that published in Conflict \\ Management and Peace Science, Vol. 29, No. 4., 2012
}

\begin{abstract}
This paper introduces two new datasets. The first is a new interstate distance dataset. It is recognised that different theories regarding distance and conflict will call for different understandings of 'distance' and accordingly, ten different types of distance measurement are presented. Moreover, it is argued that in order for a distance dataset to contain accurate distances, it is necessary for it to be based on maps reflecting state border changes over time. As such, a new map dataset is presented, including annualised maps for all states, stored in KML format. It will be shown that the frequent border changes experienced by states can have large impacts on distance calculations. The significance of the relationship between distance and conflict will be tested for the ten different types of distance measurement, not with the aim of finding a 'best measure' but in order to demonstrate that distance remains an important variable and that each different form of distance measure can be significant.
\end{abstract}

*The author is a research associate at the Richardson Institute for Conflict and Peace Research, Lancaster University, UK. The datasets presented in this paper were originally produced as part of my Ph.D. thesis and as such I would like to thank my supervisor, Feargal Cochrane, plus my examiners, Nina Caspersen and Halvard Buhaug. I would also like to thank the anonymous reviewers of this paper for their invaluable comments. The datasets referred to in this paper can be downloaded from the 'research' section of the author's website, http://www.stevepickering.net. The author can be reached at steve.pickering@gmail.com. 


\section{Introduction}

It has long been recognised that there is a relationship between distance and conflict. This paper introduces two new datasets to better understand this relationship. The first dataset presents ten different measures of interstate distance for all states between the years 1946-2010. The second dataset includes new maps of all states on an annual basis over the same temporal domain, reflecting state border changes which have occurred. There are three main reasons for introducing these new datasets. First, much existing research on distance and conflict has had to depend on hybridised data which presents methodological problems. Second, existing distance measures have been based on the assumption that state borders remain constant over time. Finally, by presenting new forms of distance measure, this paper aims to give conflict researchers new tools. This paper does not aim to find a single measure of distance which is the 'best' measure for conflict researchers to use. Instead, it aims to give conflict researchers new measures which may better fit their existing hypotheses.

\section{Why distance is relevant to conflict}

The extensive literature linking distance with conflict can be reduced to three analogies: boxers, neighbours and boils. Boxers cannot fight unless they can reach each other (Bremer 1992: 312); next-door neighbours are more likely to quarrel than those separated by several houses (Wesley 1962: 387); a boil on your neck is more worrying than famine in China 
Figure 1: Simple form of the Loss of Strength Gradient (LSG). From Boulding (1962, Fig. 12.2: 232)

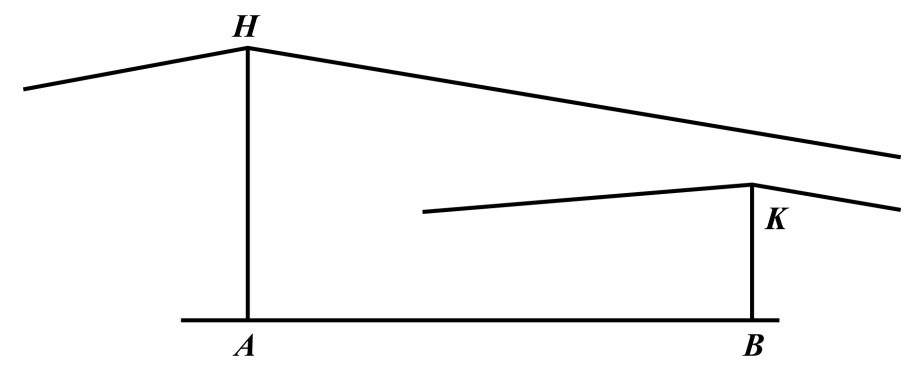

(Zipf 1949: 391). As well as three analogies, much of the distance-conflict literature depends on two frameworks: the loss of strength gradient, plus the opportunity and willingness framework.

\section{The loss of strength gradient}

Kenneth Boulding (1962) developed one of the most useful tools to understand distance decay: the loss of strength gradient (LSG). This is a law of diminishing strength, summed up in four words as, 'the further, the weaker' (Boulding 1962: 231). A state's strength ${ }^{1}$ is at its greatest within its own borders (the 'maximum home strength'); that strength diminishes as the distance from those borders increases. The area over which a state has a predominance of strength is known as its 'sphere of influence.'

To represent this idea visually, Boulding creates a series of diagrams of increasing complexity. One of the more straightforward diagrams is presented in Figure 1.

\footnotetext{
${ }^{1}$ Boulding (1962: 230) concedes that the creation of a strength variable is difficult, but felt it was possible; however, by 1989, he had decided that the creation of what he now referred to as a 'power' variable was 'virtually impossible' (Boulding 1989: 192).
} 
$\mathrm{A}$ and $\mathrm{B}$ represent states. Points $\mathrm{H}$ and $\mathrm{K}$ denote the strength of states $A$ and $B$ at home respectively. The further up the page, the greater the level of strength. Thus, the strength of state $A$ at home (represented by point $\mathrm{H}$ ) is greater than that of state $\mathrm{B}$ at home, represented by point $\mathrm{K}$. As strength is represented on the vertical axis, so distance is represented on the horizontal axis. As the distance from state $A$ increases, the diagonal line falls further down the vertical axis, indicating a loss of strength. In this diagram, the strength of state $A$ is always greater than that of state $B$, even at the point at which $B$ experiences its maximum home strength: within its own borders. To use Boulding's terminology, state B is not unconditionally viable.

\section{Opportunity and willingness}

Another useful way in which to conceptualise the importance of distance is Harvey Starr's opportunity and willingness framework (Starr and Most 1976; Starr 1978) which has been used to inform ideas such as the politically relevant international environment (PRIE, see Maoz 2000) or politically relevant neighbourhoods (see Tammen et al. 2000). Akin to the classic principles of 'means, motive and opportunity' presented in detective fiction, ${ }^{2}$ Starr looks at whether states are physically able to reach each other and whether they want to reach each other, in terms of positive or negative interactions. These principles can also be applied on a sub-state

\footnotetext{
${ }^{2}$ These methods are most relevant when considering the fact that so much of the distance/ conflict literature makes reference to Svalastoga's 1956 finding that murders tend to be committed by murderers known to the victim; a similar observation is made in Richardson 1960: 288)
} 
basis. In some cases, willingness is more important than opportunity (see, for instance, Tinbergen's 1965 observation that the UK would often allow Commonwealth ties to determine its trade flows, rather than distance). Nevertheless, the physical opportunities for actors to interact are an important factor to consider when analysing conflict.

\section{The reasons for a new distance dataset}

Two of the most widely used means of quantifying distance are inter-capital and minimum distance. Garnham (1976) concluded that interstate war was more probable between more proximate pairs of states. However, he recognised that one of the shortcomings of his analysis was that the distance between states was measured by the distance between the capital cities of the two states. A clear example of a problem facing Garnham's analysis is that of the Mexican-American War of 1846: the distance between the capitals of the two states is approximately 3,000 kilometres, yet this fails to take into account that the states in this dyad share a large land boundary. As such, Garnham states that it would have been preferable to perform the analysis using distance measurements based on the point of closest geographical proximity. However, this would require access to a large number of accurate maps.

Answering this call are Gleditsch and Ward (2001). They developed the first minimum distance database. This was a great move forward in the availability of distance data: now, a comprehensive dataset would be available providing the researcher with highly detailed information. How- 
ever, due to a lack of resources such as expensive GIS software, they had to take a visual approach to their distance analysis, rather than developing a software system that would perform the calculations for them. This meant that some compromises needed to be made, such as excluding state dyads separated by more than 950 kilometres or states with a population of less than 250,000 . As a result of this, only seven per cent of potential dyads are included in the dataset. Furthermore, the maps used in the Gleditsch-Ward dataset did not take into account changes to state boundaries, some of which can have a significant impact on distance measurements.

The dataset presented by this paper, then, covers all state dyads between the years 1946 and 2010, irrespective of size or distance, reflecting changes to state borders. As the borders of states change over time, the distances between states will vary. Also, state dyads can gain or lose contiguity over time. In order to measure the distance between states, maps have to be created of those states. One of the many issues which arises in doing this is that the number of states in existence varies over time.

\section{The formalisation of Westphalia}

In order to make the datasets presented by this paper as compatible as possible with existing research, the list of states in existence for each year was based on the lists maintained by the Correlates of War Project (COW 2008). The temporal domain of the project is $1946-2010$ and as such, the period of decolonisation is covered. This presents a challenge: be- 
fore decolonisation, should the colonies be considered as part of the territory of their colonising state? This is the perspective taken by Fearon and Laitin (2003): wars of independence from empires are civil conflicts within the imperial state. A potential issue with the Fearon and Laitin approach is the fact that different states had different colonising practices. In the post-colonial era, different practices can still be found. The French DOM-TOMs (départements et territoires d'outre mer) offer the greatest degree of institutional clarity: the DOMs are legally part of the French state (as affirmed by the French High Court: see Muller 1999: 48; Aldrich and Connell 1992: 284); the TOMs are not. Should this paper, then, take the perspective of Fearon and Laitin (2003) by considering DOMs to be a part of the territorial state of France? Taking this approach would present two problems: i) other colonising states do not provide the same degree of institutional clarity that France does regarding the DOM-TOMs; ${ }^{3}$ ii) if all of the islands, territories, departments, protectorates, administrations, military bases, etc., of states are included as part of the territory of a state, the resulting distance dataset would be rendered meaningless. Because of French Guiana, France would be literally contiguous with Suriname and Brazil and as such, theoretical arguments regarding a loss-of-strength gradient or interaction opportunities would be worthless.

\footnotetext{
${ }^{3} \mathrm{An}$ obvious case here is the Falklands/ Malvinas. This is important for students of conflict and proximity because of the distances involved. This perhaps goes some way to explaining why, as Suganami (1996: 70) observes, a strict interpretation of Correlates of War rules would exclude this conflict from the COW dataset, due to there being between 910 - 950 battle deaths (below the COW threshold of 1000). The inclusion of the conflict in the COW dataset is to some extent a fudge; similarly, including the islands as part of the territorial state of the UK would also require a fudge, as residents are afforded considerably less rights than residents of the French DOMs.
} 
As such, the concept of the metropole is employed. Generally speaking, the mainland will be considered to compose the territory of a state in question. This does not mean that all islands will be excluded; indeed, this would be impossible with archipelago states such as Indonesia. But the more distant possessions of states, however legally bound to the metropole they may be, will not be considered part of the state by this paper. ${ }^{4}$ Distant military bases will not be considered to be part of the state (although this does present future research possibilities). In the case of especially large territories which are at great distance from the metropole (such as French Guiana, or Greenland from Denmark), a separate special case has been allocated which will allow researchers to redefine state territory if their methodology requires it. The complete list of special cases for which maps have been created and distance measures included is as follows: Alaska, Falkland Islands/ Islas Malvinas, French Guiana, the Gaza Strip, Greenland, Hawaii, Puerto Rico, the contiguous 48 United States, the West Bank and Western Sahara.

As the map and distance datasets presented by this paper are based on the annual state lists developed by COW, employing the methodology discussed above means that the state map of the world for 1946 would be quite different from the same map for 2010, as can be seen in Figure 2. Essentially, the 1946 image presents the world at the end of its imperial phase; in keeping with the methodology discussed above, the white parts

\footnotetext{
${ }^{4} \mathrm{~A}$ notable exception is Hawaii. As researchers may require different understandings of the territory of the United States, several versions are included in the dataset. The standard version includes all 50 states, but there are also variants which record distance measures for the contiguous 48, Hawaii, Alaska and finally Puerto Rico separately).
} 
Figure 2: State and non-state territory: the spread of Westphalia, 1946 to 2010
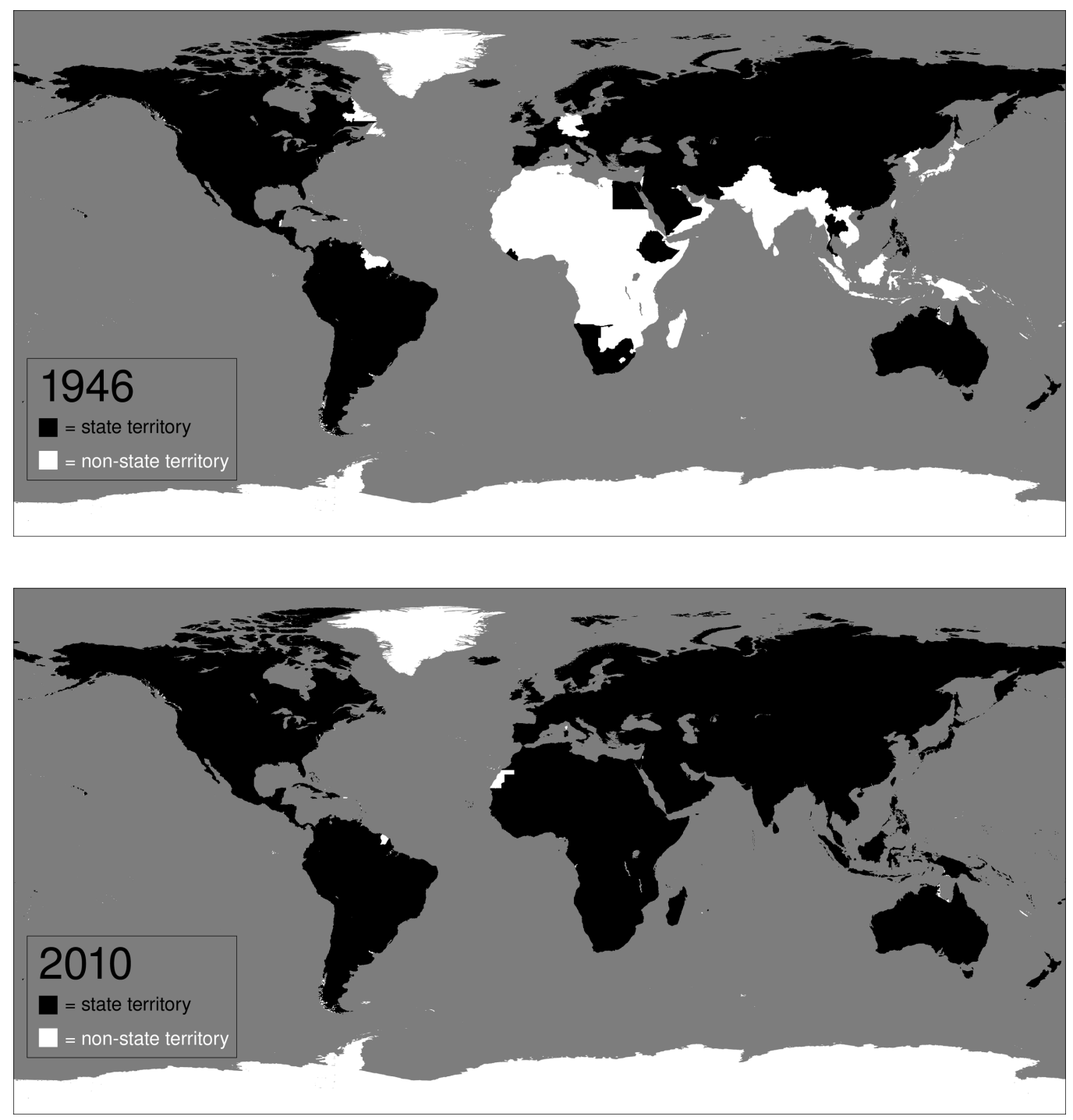
are non-state territory. By 1946, most of the world is black; the white area becomes increasingly diminished as time progresses.

\section{Changes to state boundaries included in the dataset}

The maps created for this article used four chief sources describing territorial conflicts as a starting point: Tir et al. (1998); Huth and Allee (2002); Kocs (1995); and Kornprobst (2002). In each case where the conflict may have resulted in a change to the status quo, additional state-specific texts were consulted, along with border agreements (if available) and hundreds of maps. An example is presented in Figure 3, which represents the border changes to Yugoslavia. ${ }^{5}$ The first three maps of Yugoslavia show its incorporation of the Istrian peninsula and Zone A of the 'Julian' region; the 1946-1947 map depends on the 1920 Rapallo line (see Novak 1970; Duroselle 1966), while the second and third maps move the borders west, expanding Yugoslav territory. Yugoslavia also gains territory from Hungary at the same time (see Brubaker et al. 2006). However, the last four maps show the break-up of Yugoslavia: the fourth map showing the loss of Bosnia and Herzegovina, Croatia and Slovenia; the fifth showing the separation of Macedonia; the sixth, Montenegro; finally the seventh, Kosovo.

\footnotetext{
${ }^{5}$ The latest version of the COW state system membership list was released on June 23 , 2008. For the year 2008, COW recognises a state known as Yugoslavia with the three letter codename, YUG. This is despite the fact that the Federal Republic of Yugoslavia ceased to exist on February 4, 2003, replaced on that date by the Union of Serbia and Montenegro (the state later dividing into two separate states, Montenegro on June 3, 2006, and Serbia on June 5, 2006). For the current COW membership list, then, from 2007 onwards, Serbia, which does not appear on the list, must be considered to represent Yugoslavia. This will hopefully be modified in future versions of the state list. For the maps associated with this article, then, a state known as Yugoslavia will exist in 2010. In reality, it will be what is now known as Serbia.
} 
Figure 3: Border changes to Yugoslavia, 1946-2010

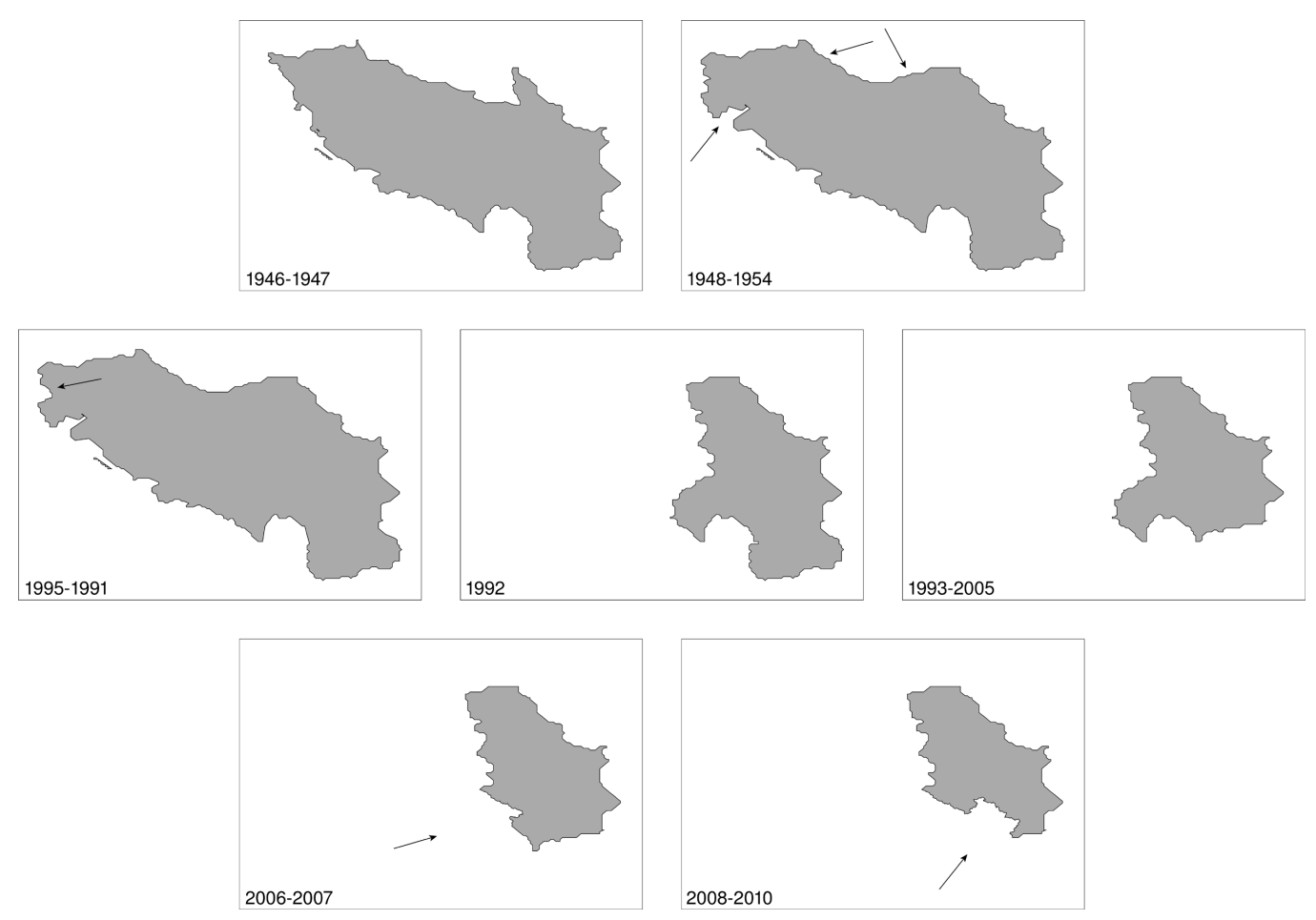


Figure 4: Changes to the border of India
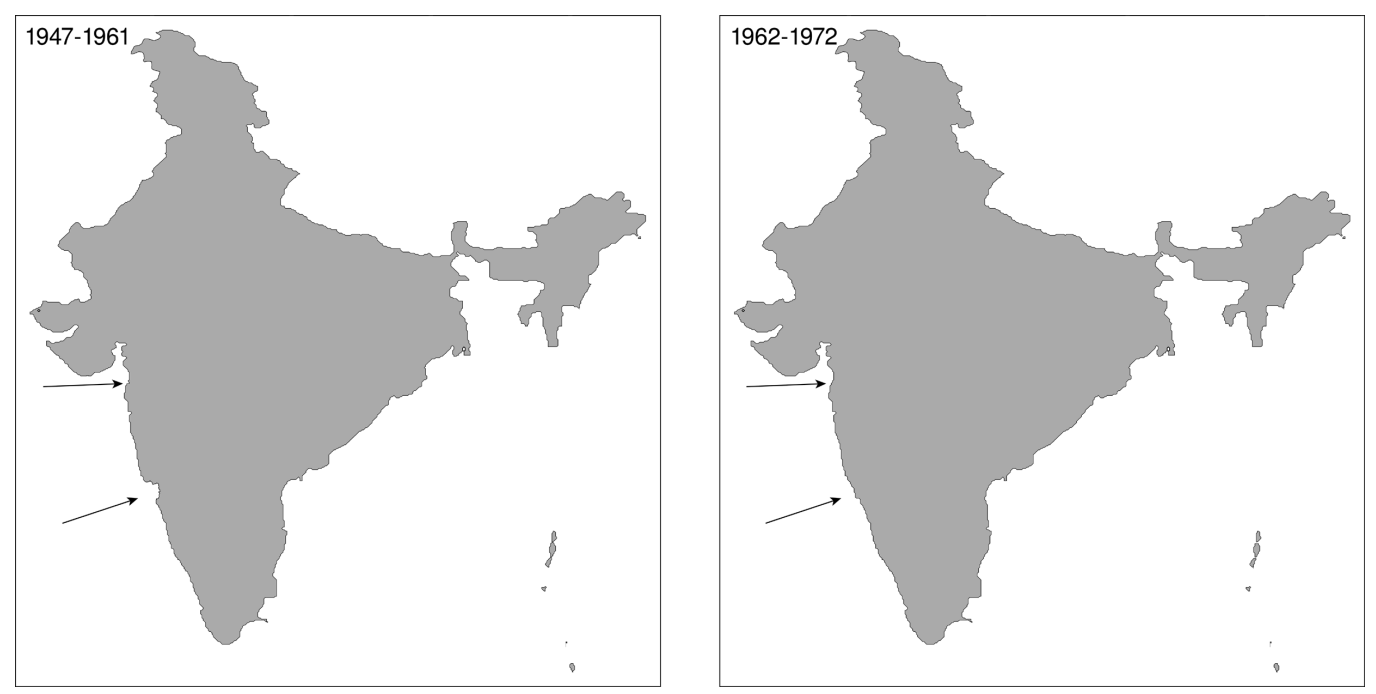

\section{Minor border changes}

While the map dataset exists in isolation from the distance dataset, it should be pointed out that the maps were created in order to create the new distance dataset. As such, the maps aim to capture as many changes to state borders as possible. Some of these changes were very small and will result in extremely minor changes to the distance dataset (see for instance the case of India in Figure 4, where India gains possession of Daman and Goa from Portugal). A very few changes were too small to be reflected in the maps at all, such as Pakistan gaining control of the small port city of Gwadar from Oman. An even smaller number of cases were excluded because they would not involve a change to an outward facing border and would therefore have no impact on distance measurements, such as the transfer of control of the inland city of Chandernagore from 
France to India (colonial city possessions tended to be coastal).

\section{Changing country shape}

Some border changes resulted in alteration of the overall 'shape of the country,' but again resulted in an only limited alteration to the distance measurements. The six maps of Saudi Arabia in Figure 5 provide an example here: as the spread of Westphalia becomes more formalised in Saudi Arabia and surrounding states, the lines in the sand are drawn evermore fixedly, but this does not result in significant changes to the distance dataset. The changing border between Hungary and Romania provides a similar example. While Hungary loses a significant amount of territory to Romania (territory which had extended as far as the Szekler region) and at the same time loses territory to what are now the Ukraine, Slovakia, Slovenia, Croatia and Serbia, these border changes still have little impact on the distance dataset.

\section{Substantial changes}

However, other border changes result in more substantial changes, such as Malaysia and Indonesia, presented in Figure 6. For Malaysia, ${ }^{6}$ we see the union of Malaya with Sabah, Sarawak and (temporarily) Singapore. For Indonesia, we see the incorporation of West Papua (Netherlands New Guinea). These both result in significant changes to the distance dataset. Similar cases include Japan's repossession of the Okinawa prefecture (the

\footnotetext{
${ }^{6} \mathrm{COW}$ recognises a state known as Malaysia as existing from the year 1957 onwards, whereas in reality it should be Malaya from 1957-1963.
} 
Figure 5: Country shape: changes to the borders of Saudi Arabia, Hungary and Romania
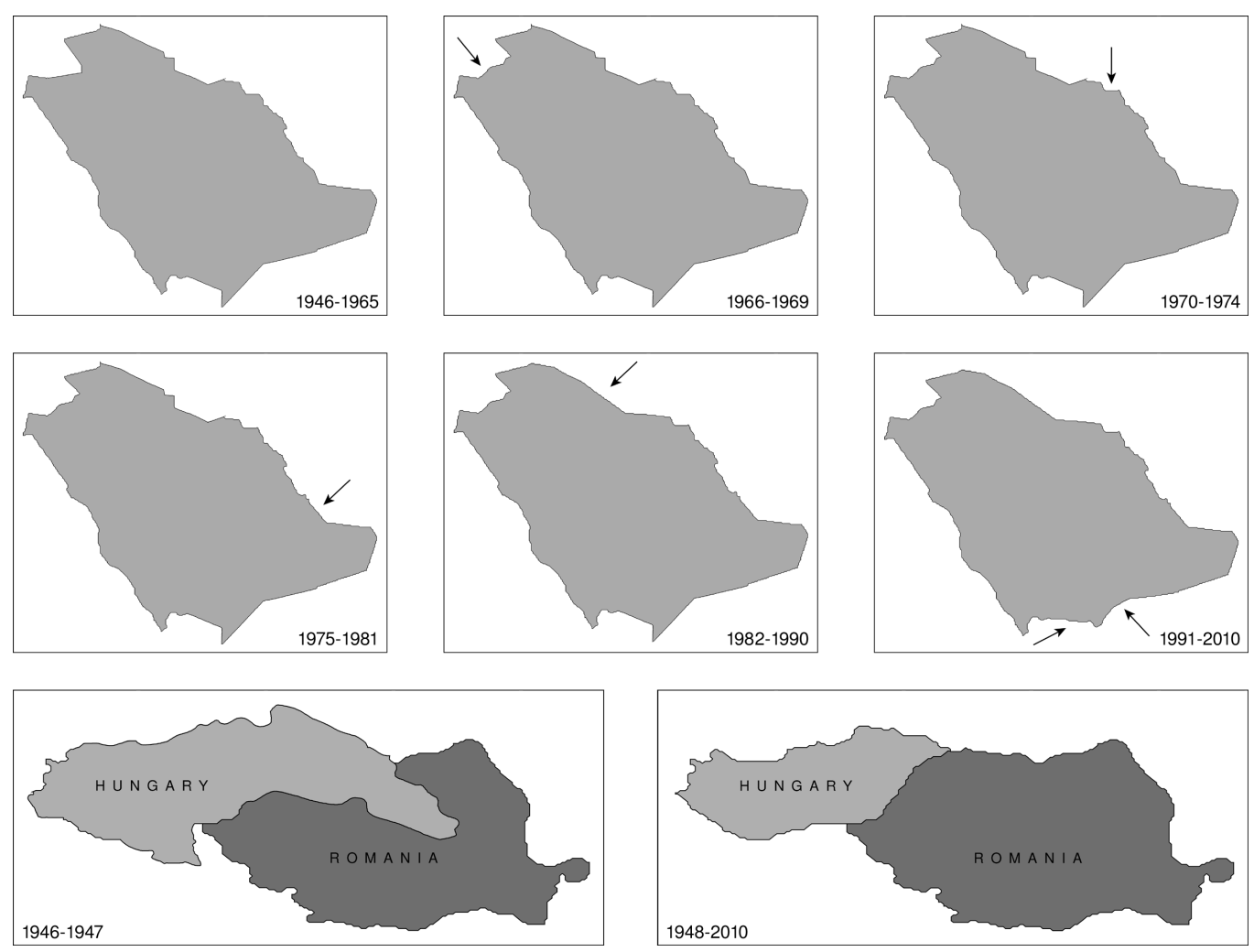
Figure 6: Changes to the territory of Malaysia and Indonesia
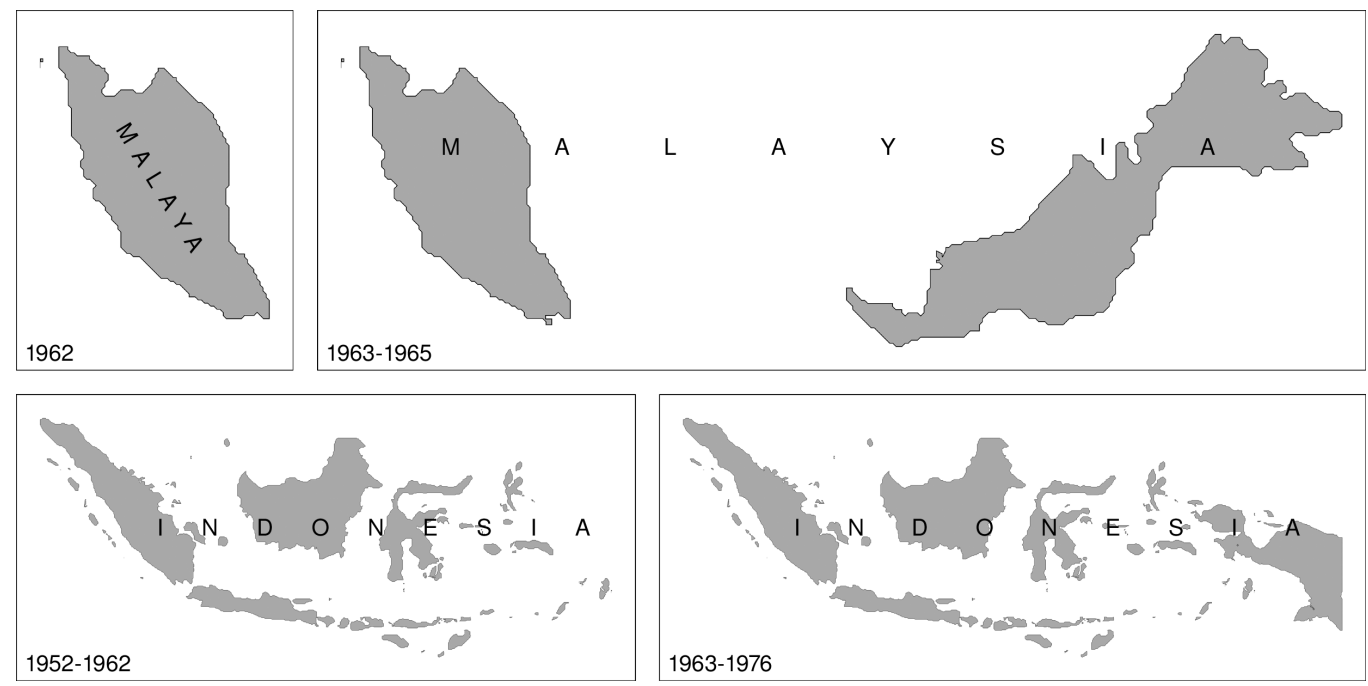

Ryukyu archipelago), Egypt's temporary union with Syria and Canada's gaining of Newfoundland.

\section{Ten different measures of interstate distance}

Lemke argues that 'researchers should specify reasons for the definition of distance they select' (Lemke 1995: 34). The distance dataset presented by this paper provides ten different measures of interstate distance which will be explained with reference to Figure 7 . Minimum distance has become one of the most widely used measures of proximity in conflict research, as its advantages are fairly clear. Gleditsch and Ward (2001) compare minimum distance with intercapital distance: 'The sizeable distance between Washington, DC, and Mexico City clearly understates the long shared border between the USA and Mexico. ... The main advantage of 
Figure 7: Ten measures of distance between Iran and Iraq. 2010 map and distance data used.

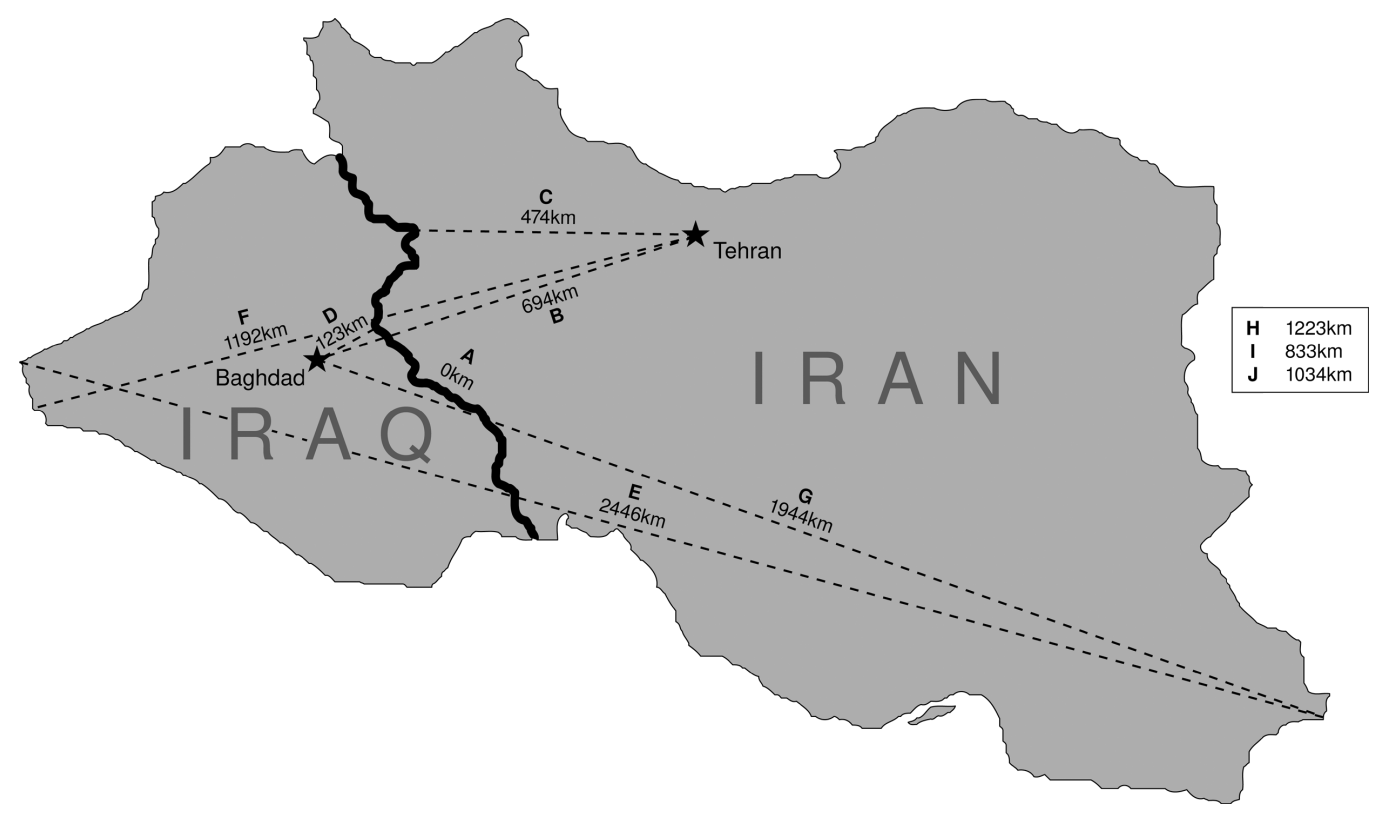

the minimum-distance database is that it can be used to derive continuous data on distances as well as to generate binary or categorized contiguity data' (Gleditsch and Ward 2001: 744-7). Lemke (1995), however, uses intercapital distance as it

makes distances between countries symmetric... Of course, inter-capital distance is a debatable choice as well, and those dissatisfied with it can use whatever definition of distance they choose... I select inter-capital distance on the assumption that capital cities generally approximate where attacks arise from, and where they are targeted. Further, inter-capital distance is symmetric, making it equally difficult for each dyad member to attack the other (Lemke 1995: 26; footnote 6: 34). 
Figure 7 presents minimum distance as 'A' (which for contiguous dyads ${ }^{7}$ such as Iran and Iraq is 0) and intercapital distance as 'B.' Lemke's assumption of symmetry is surprising, however. Earlier works do not take the perspective that attacks start and end in capital cities. Bueno de Mesquita (1981) looks at 'the distance between a nation's seat of power and the place where its power must be brought to bear in a war' (Bueno de Mesquita 1981: 83); similarly, de Vree (1982) argues that

the distance from $i$ to $j$ may well be greater than that from $\mathrm{j}$ to $\mathrm{i}$. For instance, a good strategic position is characterized precisely by the fact that those who occupy it can reach those who attack it much more easily and successfully that the other way around (de Vree 1982: 122).

A useful, if imperfect, proxy for Bueno de Mesquita's 'seat of power' could be the capital city of the first state, while the place where the 'power must be brought to bear' could be proxied in some instances as the closest point on the opposing state border. The inverse of this could also be appropriate: the 'War of the Cities' phase of the Iran-Iraq war saw armaments massed at points on the border closest to the capital city in order to launch attacks covering the least possible distance (McNaugher 1987; Chubin 1989; Hiro 1990). As such, non-symmetric measures of distance suggested above by de Vree are also included in the distance dataset. Line ' $C$ ' shows the distance from Tehran to the Iraqi border, while line ' $D$ '

\footnotetext{
${ }^{7}$ In such cases, researchers might want to consider employing a measure of border length: see for instance Furlong and Gleditsch (2003), plus the pioneering work of Lewis Fry Richardson $(1960,1961)$ and Benoit Mandelbrot (1967))
} 
shows the distance from Baghdad to the Iranian border. Line ' $E$ ' gives the opposite to minimum distance: the maximum distance between two states. While some dyads may be relatively close at the point of minimum distance, much of the territory of the two states may in reality be quite far apart. This can be more of an issue for archipelago or strangely-shaped states: the maximum distance from Micronesia to Indonesia, for instance, is four times greater than the minimum distance. Lines ' $F$ ' and ' $G$ ' give the non-symmetric capital-based counterparts to maximum distance: the maximum distance from Tehran to any point on the border of Iraq and the equivalent for Baghdad. Finally, 'H,' 'l' and 'J' (not represented as lines) give the simple mean average of the Iran-Iraq dyad, the Tehran-Iraq dyad and the Baghdad-Iran dyad.

Again, it is not the argument of this paper that one measure of distance is inherently superior to others. Instead, this paper argues that conflict researchers should let the measure fit the hypothesis. The data analysis section below shows that the different measures presented above can form useful proxies for existing hypotheses.

\section{Data analysis}

The different forms of distance measure can now be tested to see if they are significantly related to conflict. 


\section{Analysis based on Maoz' data}

The first application of the distance data to conflict data is based on Zeev Maoz' (2005) dyadic data. The temporal domain of Maoz' data is 18162001. Distance data items for this project have been generated for 19462010; as such, this analysis will be restricted to 1946-2001. This yields 553,274 non-directed dyad-years, 294 of which are war dyad-years, the unit of analysis in this case (a year in which war occurred: an on-going dispute can occur in several years).

Table 1 presents the results of logit regression tests on five different measures of distance. Models 1 and 2 present the already-existing forms of distance measure: intercapital and the Gleditsch-Ward hybrid. ${ }^{8}$ The significant relationship between conflict and these two existing measures of distance is fairly well established (see for instance Buhaug and Gleditsch 2006); the results of these models are included here for comparison. Models 3,4 and 5 are based on three of the new distance measures: minimum, maximum and mean average distance. The distance measures used in these three models are also found to have a strongly significant relationship, suggesting that these three measures may also be of use to the conflict researcher.

However, as has been discussed above, the distance dataset presented by this article also includes non-symmetrical forms of distance measure. Models for these could not be tested in Table 1 as the regres-

\footnotetext{
${ }^{8}$ As the Gleditsch-Ward minimum distance dataset includes distance measures for states separated by less than $950 \mathrm{~km}$, it is fairly common in distance-conflict literature to compile hybrid datasets of minimum distance and intercapital distance, using intercapital data to 'fill in the gaps.'
} 
Table 1: Logit regressions of distance, Maoz' dyadic conflict data, using non-directed dyads

\begin{tabular}{|c|c|c|c|}
\hline Model & Description & Incidence & Intercept \\
\hline 1 & Intercapital & $\begin{array}{l}-0.0001946^{\star \star \star} \\
(0.00001737)\end{array}$ & $\begin{array}{l}-6.3572229^{\star \star *} \\
(0.10060000)\end{array}$ \\
\hline 2 & $\begin{array}{l}\text { Gleditsch-Ward min-dist/ } \\
\text { intercapital hybrid }\end{array}$ & $\begin{array}{l}-0.0002024^{* * *} \\
(0.00001662)\end{array}$ & $\begin{array}{l}-6.3597244^{* * *} \\
(0.09234000)\end{array}$ \\
\hline 3 & Minimum distance & $\begin{array}{r}-0.0003099^{* * *} \\
(0.00002185)\end{array}$ & $\begin{array}{r}-6.1507492^{* * *} \\
(0.08537000)\end{array}$ \\
\hline 4 & Maximum distance & $\begin{array}{l}-0.0001485^{\star \star *} \\
(0.00001559)\end{array}$ & $\begin{array}{l}-6.4458098^{\star * *} \\
(0.11240000)\end{array}$ \\
\hline 5 & Average distance & $\begin{array}{c}-0.0002227^{\star \star \star} \\
(0.00001835)\end{array}$ & $\begin{array}{r}-6.2138928^{\star * \star} \\
(0.10120000)\end{array}$ \\
\hline
\end{tabular}

$\mathrm{N}=553,274$.

sions presented were based on non-directed dyadic data. The minimumcapital distance measure does not suit itself well to non-directed dyadic data, as the variable is inherently directed. As such, Table 2 reperforms the regressions, based on directed dyadic data. ${ }^{9}$ The first five models in the table follow the example set in Table 1, while models 6 and 7 present regressions of non-symmetrical, directed distance.

Model 6 can be understood as a proxy for a theory developed by Bueno de Mesquita (1981). As was mentioned earlier, he looked at the distance between a state's seat of power, and the place where that power must be used, which he in turn proxied by the locus of power of state $A$ and the minimum distance to state $B$. Model 6 , then, should provide a reasonable

\footnotetext{
${ }^{9}$ To do this, the Maoz dataset, based on Correlates of War data, was converted to a format more similar to the Uppsala/ PRIO Armed Conflict Dataset. Put simply, each line item in Maoz' dataset has variables for state $A$, state $B$, plus whether state $A$ was on side $A$ or whether state $B$ was on side $A$. The ACD avoids this issue by listing states as part of side $A$ or side $B$ variables.
} 
Table 2: Logit regressions of distance, Maoz' dyadic conflict data, using directed dyads

\begin{tabular}{|c|c|c|c|}
\hline Model & Description & Incidence & Intercept \\
\hline 1 & Intercapital & $-0.0003611^{\star * *}$ & $\begin{array}{l}-3.6945657^{\star * *} \\
(0.02267000)\end{array}$ \\
\hline & & $(0.00000553)$ & $(0.02267000)$ \\
\hline 2 & Minimum distance & $\begin{array}{l}-0.0005818^{\star \star \star} \\
(0.00000835)\end{array}$ & $\begin{array}{c}-3.5631556^{\star \star *} \\
(0.01929000)\end{array}$ \\
\hline 3 & $\begin{array}{l}\text { Gleditsch-Ward min-dist/ } \\
\text { intercapital hybrid }\end{array}$ & $\begin{array}{l}-0.000424^{* * *} \\
(0.00000580)\end{array}$ & $\begin{array}{l}-3.637321^{* * *} \\
(0.01953000)\end{array}$ \\
\hline 4 & Maximum distance & $\begin{array}{c}-0.0002221^{* \star *} \\
(0.00000425)\end{array}$ & $\begin{array}{r}-4.0093561^{* * *} \\
(0.02618000)\end{array}$ \\
\hline 5 & Average distance & $\begin{array}{l}-0.000355^{\star \star \star} \\
(0.00000557)\end{array}$ & $\begin{array}{l}-3.681874^{\star * *} \\
(0.02354000)\end{array}$ \\
\hline 6 & $\begin{array}{l}\text { Capital to minimum } \\
\text { state edge }\end{array}$ & $\begin{array}{c}-0.0004477^{\star \star *} \\
(0.00000658)\end{array}$ & $\begin{array}{r}-3.6195813^{* \star \star} \\
(0.02113000)\end{array}$ \\
\hline 7 & $\begin{array}{l}\text { Minimum state } \\
\text { edge to capital }\end{array}$ & $\begin{array}{c}-0.0004477^{\star * \star} \\
(0.00000658)\end{array}$ & $\begin{array}{r}-3.6195781^{* * *} \\
(0.02113000)\end{array}$ \\
\hline
\end{tabular}

$\mathrm{N}=1,228,892$. 
proxy for Bueno de Mesquita's theory (although it is recognised that the capital city may not be the locus of power). Model 7 , on the other hand, works from the opposite assumption: it takes the perspective that attacks will arise from the edge of a potential attacker, and culminate at the capital of the intended victim. Returning to an earlier point, Lemke decided to use intercapital data, as he felt that attacks tend to arise in capitals and are aimed at other capitals. This is a curious assumption to make. Some conflicts do have the opponent's capital city as the target (such as the War of the Cities, discussed earlier). But it seems less reasonable to assume that an attack on a capital city would arise from a capital city; it would make more sense for attacks to arise ${ }^{10}$ from the territory of state $A$ closest to that of state B: the Iraqi invasion of Kuwait, in which Kuwait City was taken by troops which had been stationed on the border (Niva 1991: 55-6; Mylroie 1996: 45-8) and the Soviet attack on Budapest in 1956 (Méray 1959: 237) provide examples of this. ${ }^{11}$

All of the distance measures presented in this section have been shown to have a significant relationship with conflict. As was stated earlier, it is not the aim of this paper to find a single 'best' measure of distance for conflict

\footnotetext{
${ }^{10}$ Part of the difficulty here is in defining 'arise.' A capital city may well have more troops garrisoned than other parts of the state, due in part to the fact that it may be one of the largest population centres. Where, then, are the troops embarking from? Does an attack 'arise' when armed forces leave state A bound for state B, when the army barracks is first built, or at some time in between? Determining where armed forces came from depends in great part on when we start looking. When considering the logistics of the global political chessboard on which the armed forces of the United States operate, this is a tremendously complicated issue.

${ }^{11}$ The US' involvement in Korea goes a step further: troops were already stationed outside of the US. The day after President Truman committed ground forces to the Korean conflict, US troops started moving from Japan to Korea. See Paul 1973; Landsdown 2006; Marolda 2007.
} 
researchers. Rather, the aim is to give researchers tools which may better fit their hypotheses. The distance measure used in Model 7, for instance, shows that researchers following the example of Lemke's relevant dyads could consider minimum state edge to capital data as an alternative to intercapital data.

\section{Analysis based on Buhaug and Gleditsch's data}

Buhaug and Gleditsch (2006) also looked at the relationship between distance and conflict. They performed a multivariate regression using variables such as alliances, major powers and democracies.

Table 3 reproduces their analysis on the more limited timeframe of 1946-1998. The 'a' models are based on non-war MIDs, the 'b' models are wars, while the ' $c$ ' models are wars and non-war MIDs combined. The Gleditsch-Ward 950km minimum/ intercapital distance hybrid is tested (the measure used in Buhaug and Gleditsch 2006), along with natural logged versions of the new minimum, average and maximum distance. As was the case in the earlier analysis of Maoz' data, all of the distance measures are found to have a significant relationship with conflict. This suggests that researchers could consider using alternative distance measures when their hypotheses call for them.

Interesting results are found when looking at the probability data presented by Buhaug and Gleditsch. They observe that '[a]ccording to Model 1 , two states separated by the 5 th percentile value $(412 \mathrm{~km})$ are more than three times as likely to be in a dispute as a dyad with the 95th per- 
Figure 8: Relative probability of MID (including war) at distance percentiles.

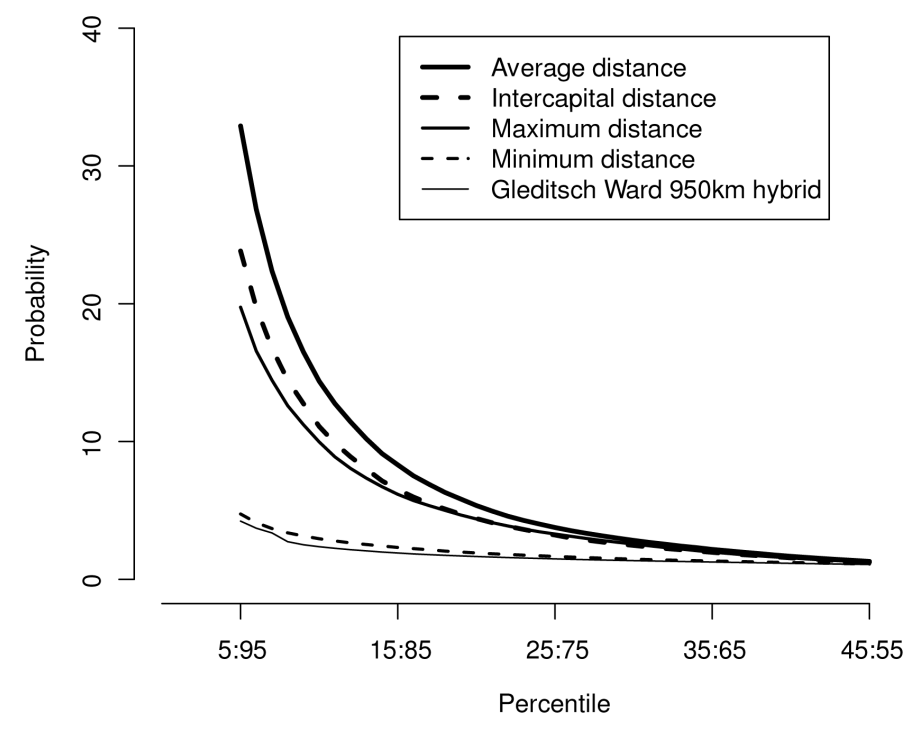

1946-1998 data.

centile value (15,835 km).' Table 4 uses Model 1 and tests conflict probability based on five different forms of distance measurement. Figure 8 presents the probabilities at several different distance percentiles. The distance measure with the greatest probability differences is average distance: states separated by a 5th percentile mean average distance are almost 33 times more likely to be engaged in conflict than states separated by the 95th percentile mean average distance. Intercapital and maximum distance also show strong differences. This is important, as researchers using a hybrid of minimum and intercapital distance should be aware that separately, the two distance measures yield very different conflict probabilities. 


\section{Conclusion}

While the overall relationship between distance and conflict has been fairly well understood for some time, an element of doubt has remained. Existing datasets have been incomplete (limited to state dyads separated by $950 \mathrm{~km}$ or less), inconsistent (based on hybridised minimum and intercapital data, two forms of distance measure which, as this article has shown, yield very different probability results), and based on non-contemporaneous maps. As was pointed out earlier, Lemke argues that 'researchers should specify reasons for the definition of distance they select' (Lemke 1995: 34). It may be the case that intercapital distance is better for understanding cultural similarities and ties, whereas minimum distance is of more use in explaining trade or tourism. The distance dataset presented by this article presents eight new measures for the researcher to consider.

Since the height of the Cold War, researchers have been arguing that distance is no longer a factor in conflict research. Yet Buhaug and Gleditsch (2006: 198) made the case that the death of distance has 'probably been prematurely announced.' This article agrees with their finding. There are still areas of research in distance and conflict which still need to be explored. The impact of distance on interaction opportunities is most important and new research on overseas military bases and the relative size and location of states should yield useful new findings. The importance of distance to civil conflict has only been acknowledged relatively recently and in this area too there is much ground to cover. It is hoped that the new distance datasets presented by this article will be of use to researchers, 
whether they are looking at distance and conflict directly, or using distance as a control variable. It is also hoped that the new set of maps presented by this paper will also be of use to researchers.

\section{Bibliography}

Aldrich, Robert and John Connell, France's Overseas Frontier: Départements et Territoires D'Outre-Mer, Cambridge: Cambridge University Press, 1992.

Boulding, Kenneth, Conflict and Defense: A General Theory, New York: Harper Torchbooks, 1962.

Boulding, Kenneth (1989), Three Faces of Power, Sage: Newbury Park, CA.

Bremer, Stuart A., 'Dangerous Dyads: Conditions Affecting the Likelihood of Interstate War, 1816 - 1965,' Journal of Conflict Resolution, Vol. 36, No. 2, June 1992, pp. 309-341.

Brubaker, Roger, Margit Feischmidt, Jon Fox, Liana Grancea, Nationalist Politics and Everyday Ethnicity in a Transylvanian Town, Princeton, NJ: Princeton University Press, 2006.

Bueno de Mesquita, Bruce, The War Trap, New Haven, CT: Yale University Press, 1981.

Buhaug, Halvard and Nils Petter Gleditsch, 'The death of distance? The globalization of armed conflict,' in Miles Kahler and Barbara F. Walter (eds.), Territoriality and Conflict in an Era of Globalization, Cambridge: Cambridge University Press, 2006, pp. 187 - 216.

Chubin, Shahram, 'Iran and the War: From Stalemate to Ceasfire,' 
in Efraim Karsh (ed.), The Iran-Iraq War:Impact and Implications, Basingstoke: MacMillan, 1989.

Correlates of War Project. 2008. "State System Membership List, v2008.1." Online, http://correlatesofwar.org.

Duroselle, Jean-Baptiste, Le Conflit de Trieste, 1943 - 1954, Brussels: Editions de l'Institut de Sociologie de l'Universite Libre de Bruxelles, 1966.

Fearon, James D. and David D. Laitin, 'Ethnicity, Insurgency, and Civil War,' The American Political Science Review, Vol. 97, No. 1 (Feb., 2003), pp. $75-90$.

Furlong, Kathryn and Nils Petter Gleditsch, 'The Boundary Dataset,' Conflict Management and Peace Science, Vol. 20, No. 1, 2003, pp. 93117

Garnham, David, 'Dyadic International War 1816 - 1965: The Role of Power Parity and Geographical Proximity,' Western Political Quarterly 29, 1976 pp. $231-242$.

Gleditsch, Kristian S. and Michael Ward, 'Measuring Space: A MinimumDistance Database and Applications to International Studies,' Journal of Peace Research, Vol. 38, No. 6, 2001, pp. 739-758.

Hiro, Dilip, The Longest War: The Iran-Iraq Military Conflict, London: Paladin, 1990.

Huth, Paul K., and Todd L. Allee, The Democratic Peace and Territorial Conflict in the Twentieth Century Cambridge: Cambridge University Press, 2002.

Kocs, Stephen A., 'Territorial Disputes and Interstate War, 1945-1987,' The Journal of Politics, Vol. 57, No. 1 (Feb 1995), pp. 159-75. 
Kornprobst, Marcus, 'The Management of Border Disputes in African Regional Sub-systems: Comparing West Africa and the Horn of Africa,' Journal of Modern African Studies, 40, 3 (2002), pp. 369-393.

Landsdown, Richard (ed.), Strangers in the South Seas: The Idea of the Pacific in Western Thought: An Anthology, Honolulu: University of Hawai'i Press, 2006.

Lemke, Douglas, 'The Tyrrany of Distance: Redefining Relevant Dyads,' International Interactions, 1995, Vol. 21, No. 1, pp. 23-38.

Mandelbrot, Benoit, 'How Long is the Coast of Britain? Statistical SelfSimilarity and Fractional Dimension,' Science, Vol. 156, 5 May 1967, pp. 636-8.

Maoz, Zeev, 'Alliances: the street gangs of world politics - their origins, management, and consequences, 1816-1986', in John A. Vasquez (ed.), What do we know about war?, Lanham, MD: Rowman and Littlefield Publishers, Inc., 2000 (pp. 111 - 144).

Maoz, Zeev (2005). Dyadic MID Dataset (version 2.0):

http://psfaculty.ucdavis.edu/zmaoz/dyadmid.html.

Marolda, Edward J. (ed.), The US Navy in the Korean War, Annapolis, MD: Naval Institute Press, 2007.

McNaugher, Thomas L., 'Walking Tightropes in the Gulf,' in Efraim Karsh (ed.), The Iran-Iraq War: Impact and Implications, Basingstoke: MacMillan, 1987.

Méray, Tibor, Thirteen Days That Shook the Kremlin, trans. Howard L. Katzander, London: Thames and Hudson, 1970.

Muller, Karis, 'Problems of European Union Citizenship Rights at the 
Periphery,' Australian Journal of Politics and History, Vol. 45, No. 1, 1999, pp. 35-51.

Mylroie, Laurie, 'Saddam Hussein's Invasion of Kuwait: A Premeditated Act,' in Wolfgang F. Danspeckgruber and Charles R.H. Tripp (eds.), The Iraqi Aggression Against Kuwait: Strategic Lessons and Implications for Europe, Oxford: Westview Press, 1996, pp. 39-50.

Novak, Bogdan C., Trieste, 1941 - 1954: The Ethnic, Political, and Ideological Struggle, Chicago: University of Chicago Press, 1970.

Niva, Steve, 'The Battle is Joined,' in Phyllis Bennis and Michel Moushabeck (eds.), Beyond the Storm: A Gulf Crisis Reader, Brooklyn, NY: Olive Branch Press, 1991, pp. 55-71.

Paul, Ronald A., American Military Commitments Abroad, New Jersey: Rutgers University Press, 1973.

R Development Core Team (2009). R: A language and environment for statistical computing. R Foundation for Statistical Computing, Vienna, Austria. ISBN 3-900051-07-0, URL http://www.R-project.org.

Richardson, Lewis Fry, Statistics of Deadly Quarrels, London: Stevens, 1960.

Richardson, Lewis Fry, 'The Problem of Contiguity: An Appendix to Statistics of Deadly Quarrels,' General Systems: Yearbook of the Society for General Systems Research, Vol. VI, 1961, pp. 139-187.

Starr, Harvey and Benjamin A. Most, 'The Substance and Study of Borders in International Relations Research,' International Studies Quarterly, Vol. 20, No. 4, Dec. 1976, pp. 581-620.

Starr, Harvey, "Opportunity" and "Willingness" as Ordering Concepts 
in the Study of War,' International Interactions, Vol. 4, No. 4, June 1978, pp. 363-87.

Suganami, Hidemi, On The Causes Of War, Oxford: Clarendon Press, 1996.

Svalastoga, Koare, 'Homicide and Social Contact in Denmark,' American Journal of Sociology, 62, July 1956.

Tammen, Ronald L., Jacek Kugler, Douglas Lemke, Allan C. Stam III, Carole Alsharabati, Mark Andrew Abdollahian, Brian Efird, A.F.K. Organski, Power Transitions: Strategies for the 21st Century New York: Chatham House Publishers, 2000

Tinbergen, Jan, International Economic Integration (second revised edition), Amsterdam: Elsevier, 1965.

Tir, Jaroslav, Philip Schafer, Paul F. Diehl, Gary Goertz, 'Territorial Changes, 1816-1996: Procedures and Data,' Conflict Management and Peace Science, Vol. 16, No. 1, 1998, pp. 89-97.

Vree, Johan K. de, Foundations of Social and Political Processes: The Dynamics of Human Behavior, Politics and Society. Vol. 1: Theory. Bilthoven: Prime Press, 1982.

Wesley, James Paul, 'Frequency of Wars and Geographical Opportunity' [research notes], The Journal of Conflict Resolution, Vol. 6, No. 4 (Dec., 1962), pp. 387-389.

Zipf, George Kingsley, Human Behavior and the Principle of Least Effort: An Introduction to Human Ecology, New York: Hafner, 1949. 


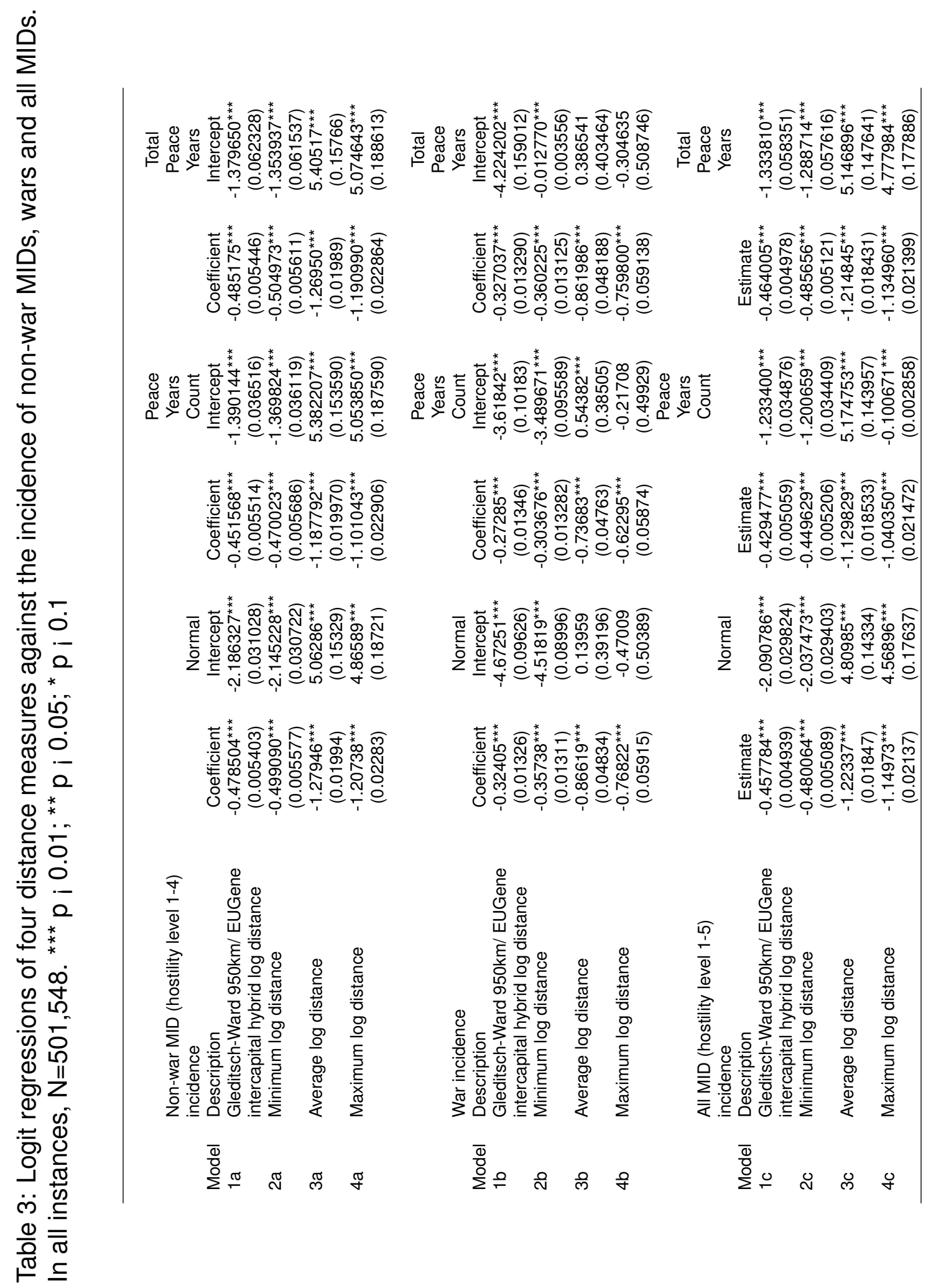


Table 4: Probability of MIDs comparing 5th with 95th distance percentiles, based on different measures of distance

\begin{tabular}{|c|c|c|c|}
\hline & $\begin{array}{l}\text { 5th percentile } \\
(\mathrm{km})\end{array}$ & $\begin{array}{l}\text { 95th percentile } \\
(\mathrm{km})\end{array}$ & Probability \\
\hline $\begin{array}{l}\text { Gleditsch-Ward } \\
950 \mathrm{~km} \text { hybrid }\end{array}$ & 552 & 15987 & 4.223781 \\
\hline $\begin{array}{l}\text { Minimum } \\
\text { distance }\end{array}$ & 507 & 14847 & 4.740327 \\
\hline $\begin{array}{l}\text { Maximum } \\
\text { distance }\end{array}$ & 2083 & 17155 & 19.74926 \\
\hline $\begin{array}{l}\text { Intercapital } \\
\text { distance }\end{array}$ & 1297 & 15987 & 23.82902 \\
\hline $\begin{array}{l}\text { Average } \\
\text { distance }\end{array}$ & 1411 & 15928 & 32.90504 \\
\hline
\end{tabular}

